\title{
Pengembangan Bahan Ajar Gamifikasi pada Materi Himpunan
}

\author{
Yosi Marenda Wirawan'*, Rizki Wahyu Yunian² \\ ${ }^{1}$ SMK Amal Bakti Jatimulyo, JL. Panembahan Senopati, Jatimulyo, Kabupaten Lampung Selatan, \\ Lampung 35365 \\ 2Universitas Islam Negeri Raden Intan Lampung. Jalan Endro Suratmin, Sukarame, Bandar \\ Lampung 35133, Indonesia. \\ * Corresponding Author. E-mail: yosimarenda1@ gmail.com
}

Received : 13-08-2018; Revised : 19-09-2018; Accepted : 30-09-2018

\begin{abstract}
Abstrak
Tujuan penelitian ini adalah untuk mengetahui apakah pengembangan bahan ajar gamifikasi pada materi himpunan untuk siswa kelas VII layak dan menarik untuk digunakan di sekolah SMP. Subjek uji coba dalam penelitian ini adalah siswa kelas VII SMP di Bandar Lampung. Metode penelitian ini adalah Research and Development (R\&D), yang menggunakan model pengembangan Brog and Gall. Hasil penelitian adalah: penilaian ahli materi memberikan skor dengan persentase rata-rata $76 \%$ dikategorikan sangat layak, ahli media atau desain memberikan skor dengan persentase rata-rata $71 \%$ dikategorikan layak dan ahli bahasa memberikan skor dengan persentase rata-rata $69 \%$ dikategorikan layak. Pada uji coba kelompok kecil, diperoleh rata-rata 3,6 dengan kategori sangat menarik. Pada uji coba lapangan diperoleh rata-rata 3,4 dengan kategori sangat menarik serta respon guru terhadap bahan ajar gamifikasi diperoleh rata-rata 3,3 dengan kriteria sangat menarik. Sehingga dapat disimpulkan bahwa bahan ajar gamifikasi ini dikategorikan sangat menarik dan layak untuk digunakan dalam pembelajaran matematika di sekolah SMP.
\end{abstract}

Kata kunci: Pengembangan, Bahan Ajar, Gamifikasi.

\begin{abstract}
The purpose of this study is to know whether the development of teaching materials gamification for seventh-grade students is feasible and interesting for use in junior high school. The subjects of the experiment were seventh-grade students at SMP Bandar Lampung. This research method is Research and Development (R\&D), which a using Borg and Gall development model. The results of the assessment are: the expert assessment of the material giving a scored with an average percentage of $76 \%$ is categorized as highly feasible, the media or design experts scored with an average percentage of $71 \%$ categorized as feasible and the linguist gave a score with an average percentage of $69 \%$ categorized as feasible. In small group trials, an average of 3,6 was obtained with very attractive and feasible categories. In the field trial, it was found that the average of 3,4 was obtained with very attractive and feasible categories and the teacher's response to the materials gamifikasi, it was found that the average of 3,3 was obtained with very attractive and feasible categorized. So it can be concluded that the gamification teaching materials on the are categorized very attractive and feasible for use in mathematics learning in junior high school.
\end{abstract}

Keywords: Development, Teaching Materials, Gamification. 


\section{Desimal, 1 (3), 2018 - 330 \\ Yosi Marenda Wirawan, Rizki Wahyu Yunian}

\section{PENDAHULUAN}

Pada era global saat ini, hasil yang ingin diraih dari pendidikan tidak hanya sekedar ilmu atau pengetahuan, melainkan menumbuh kembangkan karakter yang baik pada siswa dan mengembangkan softkill siswa. Didalam pencapaian tersebut kita juga memerlukan kurikulum yang baik, tepat dan layak untuk digunakan pada pendidikan sekarang ini. Kurikulum merupakan alat mencapai tujuan pendidikan yang diharapkan dapat meringankan sebagian tugas pendidik dalam proses belajar mengajar yang efektif dan efisien (Idi, 2014:165). Kurikulum di Indonesia pernah sebelas kali mengalami perubahan dan krikulum pada saat ini yaitu Kurikulum 2013 (Wekke \& Astuti, 2017:34).

Hasil wawancara siswa SMP/MTs di Bandar Lampung, menyatakan bahwa mata pelajaran matematika merupakan mata pelajaran yang sangat rumit karena selalu berhubungan dengan angka serta terlalu banyak rumus-rumus yang ditemui. Selain itu, matematika juga merupakan mata pelajaran yang membosankan dan kurang menarik karena proses belajar yang dilakukan hanya seperti itu saja tanpa adanya bahan ajar yang baru seperti bahan ajar yang menggunakan banyak gambar-gambar. Mereka lebih suka bahan ajar yang banyak gambarnya dibandingkan dengan bahan ajar teks.

Menyikapi fenomena yang terjadi, maka akan lebih baik jika kita perlu mengembangkan bahan ajar yang layak dan menarik agar siswa merasa ingin dan ingin lagi untuk belajar matematika, tidak pernah merasa bosan dan selalu memperhatikan materi pembelajaran yang disampaikan oleh guru sampai proses pembelajaran selesai. Bahan ajar tersebut salah satunya adalah bahan ajar gamifikasi.

Berdasarkan hasil penelitian terdahulu, telah dilakukan penelitian untuk mengembangkan bahan ajar TIK SMP mengacu pada pembelajaran berbasis proyek (Aisyi et al., 2013:117), mengembangkan bahan ajar materi aritmetika sosial menggunakan konteks bahan bakar minyak dengan pendekatan pendidikan matematika realistik indonesia di SMP (Wati, Zulkardi, \& Susanti, 2015:1) dan mengembangkan bahan ajar interaktif berbasis komputer pokok bahasan lingkaran untuk kelas VIII sekolah menengah pertama (Malalina \& Kesumawati, 2013:55). Perbedaan dengan produk yang dikembangkan peneliti yaitu peneliti mengembangkan bahan ajar gamifikasi pada materi himpunan untuk siswa kelas VII SMP.

Penelitian selanjutnya, peneliti mengembangkan bahan ajar gamifikasi pada materi bangun ruang sisi lengkung (Farida, Khoirunnisa, and Putra 2018:193), menggunakan gamifikasi dalam proses pembelajaran. Perbedaan dengan produk yang dikembangkan peneliti yaitu peneliti mengembangkan bahan ajar gamifikasi dengan materi yang berbeda yaitu materi himpunan.

Berdasarkan uraian di atas peneliti tertarik untuk melakukan penelitian yaitu: bagaimana pengembangan bahan ajar gamifikasi pada materi himpunan untuk siswa kelas VII yang layak dan menarik untuk digunakan di sekolah SMP. Penulis berharap dengan dikembangkannya bahan ajar gamifikasi pada materi himpunan dapat membantu peserta didik dalam melakukan pembelajaran matematika disekolah khususnya siswa kelas VII SMP. 
Desimal, 1 (3), 2018 - 331

Yosi Marenda Wirawan, Rizki Wahyu Yunian

\section{METODE}

Metode penelitian ini adalah Research and Development (R\&D), Brog and Gall yang disederhanakan menjadi 7 langkah utama dan disesuaikan dengan penelitian yang akan dilakukan, yaitu: Potensi dan Masalah, Mengumpulkan
Informasi, Desain Produk, Validasi Produk, Revisi Produk, Uji Coba Produk dan Revisi Produk. Secara umum, pengembangan produk terlihat pada Gambar 1.

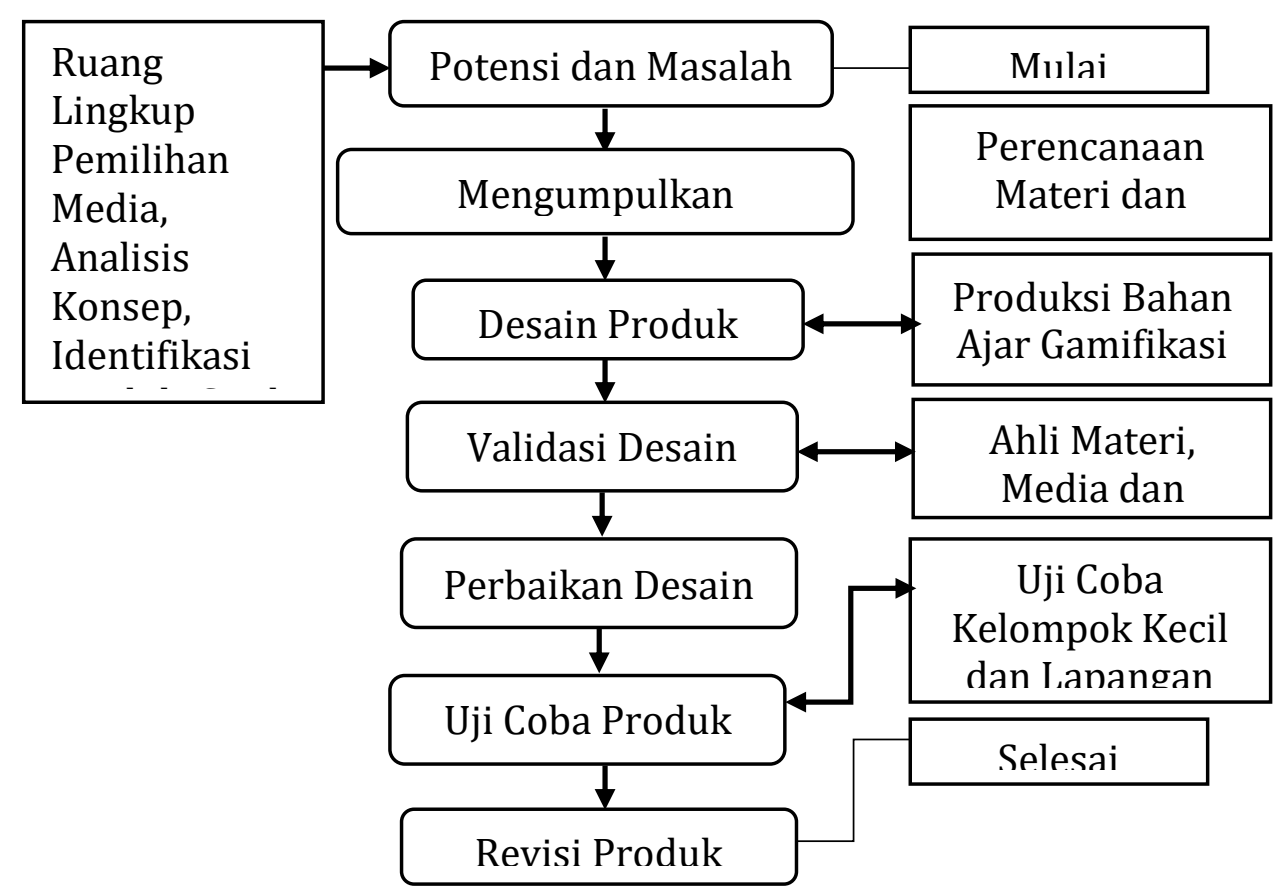

Gambar 1. Tahapan Pengembangan Penelitian 
Teknik pengumpulan data dalam penelitian ini adalah wawancara dan penyebaran angket skala likert dan instrumen yang dilakukan dalam penelitian ini adalah lembar validasi dan angket. Teknik analisis data yang digunakan pada penelitian ini yaitu menggunakan teknik analisis data deskriptif kualitatif. Data yang diperoleh melalui instrumen uji coba dianalisis dengan menggunakan statistik deskriptif kualitatif.

Teknik analisis data hasil validasi ahli memiliki 4 jawaban sesuai konten pernyataan. Masing-masing pilihan jawaban memiliki skor berbeda. Skor penilaian validasi ahli dari tiap pilihan jawaban dapat dilihat dalam Tabel 1.

\section{Tabel 1. Skor Penilaian Validasi Ahli}

\begin{tabular}{cc}
\hline Skor & Pilihan Jawaban Kelayakan \\
4 & Sangat baik \\
3 & Baik \\
2 & Kurang baik \\
1 & Sangat Kurang baik \\
\hline
\end{tabular}

Skor penilaian total dalam analisa data diatas dapat dicari dengan rumus sebagai berikut:

Keterangan:

$$
\mathrm{P}=\frac{\sum n_{i}}{N} \times 100 \%
$$

$\mathrm{P} \quad=$ persentase skor penilaian

$\sum n_{i} \quad=$ skor yang diperoleh

$\mathrm{N} \quad=$ skor maksimal

Kemudian dikelompokkan dalam kriteria skor penilaian validasi ahli untuk menentukan kualitas dan tingkat kelayakan bahan ajar gamifikasi pada materi himpunan. Kriteria skor penilaian validasi ahli dapat dilihat dalam Tabel 2 .

Tabel 2. Kriteria Penilaian Validasi Ahli

\begin{tabular}{cc}
\hline Skor Kualitas & Kriteria Kelayakan \\
$0<P \leq 25 \%$ & Sangat Kurang Layak \\
& Digunakan \\
$25 \%<P \leq 50 \%$ & Kurang Layak Digunakan \\
$50 \%<P \leq 75 \%$ & Layak Digunakan \\
$75 \%<P \leq 100 \%$ & Sangat Layak Digunakan \\
\hline
\end{tabular}

Sedangkan teknik analisis data hasil angket respon memiliki 4 pilihan jawaban sesuai konten pertanyaan. Masing-masing jawaban memilki skor berbeda yang mengartikan tingkat kemenarikan produk bagi pengguna. Skor penilaian dari tiap pilihan jawaban dapat dilihat dalam Tabel 3.

Tabel 3. Skor Penilaian

Terhadap Pilihan Jawaban

\begin{tabular}{cc}
\hline Skor & Pilihan Jawaban Kemenarikan \\
4 & Sangat Setuju \\
3 & Setuju \\
2 & Kurang Setuju \\
1 & Sangat Kurang Setuju \\
\hline
\end{tabular}

Data yang terkumpul tersebut, selanjutnya akan dianalisis dan dicari skor penilaian total dengan menggunakan rumus sebagai berikut:

Dengan :

$$
\begin{gathered}
\bar{x}=\frac{\sum_{i=1}^{n} x_{i}}{n} \\
x_{i}=\frac{\text { jumlah skor }}{\text { skor maks }} \times 4
\end{gathered}
$$

Keterangan:

$\bar{x}=$ rata-rata akhir

$x_{i}=$ nilai uji operasional angket tiap siswa

$n=$ banyaknya siswa yang mengisi angket

Dalam penkonversian skor kemenarikan produk, digunakan kriteria skor untuk uji kemenarikan ini dapat dilihat dalam Tabel 4.

Tabel 4. Kriteria Skor

Untuk Uji Kemenarikan

\begin{tabular}{cc}
\hline Skor Kualitas & $\begin{array}{c}\text { Pertanyaan Kualitas } \\
\text { Aspek Kemenarikan }\end{array}$ \\
$3,26<\bar{x} \leq 4,00$ & Sangat Menarik \\
$2,51<\bar{x} \leq 3,26$ & Menarik \\
$1,76<\bar{x} \leq 2,51$ & Kurang Menarik \\
$1,00<\bar{x} \leq 1,76$ & Sangat Kurang Menarik \\
\hline
\end{tabular}

\section{HASIL DAN PEMBAHASAN}

Berdasarkan penelitian mengenai pengembangan bahan ajar gamifikasi 
pada pembelajaran matematika untuk siswa kelas VII SMP yang telah dilakukan, diperoleh hasil penelitian sebagai berikut:

\section{Potensi dan Masalah}

Identifikasi masalah pada penelitian ini dilakukan dengan wawancara dengan guru bidang studi Matematika kelas VII. Berdasarkan permasalahan pada tahap potensi dan masalah yang telah dikemukakan dalam hasil penelitian diketahui bahwa dalam proses pembelajaran di kelas pendidik masih menggunakan metode konvensional, metode diskusi dan hanya memanfaatkan internet dan buku paket yang sudah disediakan di sekolah sebagai bahan ajar.

\section{Mengumpulkan Informasi}

Dalam proses pengembangan produk ini, peneliti mengumpulkan informasi tentang bahan ajar yang digunakan di sekolah baik berupa silabus pembelajaran matematika SMP, buku paket, buku sekolah elektronik (BSE), modul pendalaman materi dan soal sukses menggapai ujian nasional. Selain itu, peneliti juga mengumpulkan gambargambar yang berhubungan dengan bahan ajar gamifikasi yang dibuat dari dokumen pribadi peneliti ataupun mencari dari internet.

\section{Desain Produk}

Tahap ini merupakan tahap dimana objek bahan ajar gamifikasi pada materi himpunan dibuat. Penyusunan bahan ajar gamifikasi ini disesuaikan dengan kompetensi dasar yang termuat pada kurikulum 2013. Bahan ajar gamifikasi ini menggunakan ukuran kertas B5; skala space 1,5; font $12 \mathrm{pt}$; jenis huruf Comic Sans MS.

\section{Validasi Desain}

Pengembangan bahan ajar gamifikasi pada materi himpunan dengan melakukan evaluasi oleh para ahli dan praktisi pendidikan yang disebut dengan validasi. Dari masing-masing penilaian yang diberikan oleh validator ahli dan praktisi pendidikan. Untuk hasil validasi, yaitu sebagai berikut:

Tabel 5. Hasil Validasi oleh Ahli Materi

\begin{tabular}{cc}
$\begin{array}{c}\text { Persentase }(\%) \\
\text { rata skor }\end{array}$ & Kriteria \\
$76 \%$ & Sangat Layak \\
\hline
\end{tabular}

Tabel 6. Hasil Validasi

oleh Ahli Media atau Desain

\begin{tabular}{cc}
$\begin{array}{c}\text { Persentase }(\%) \\
\text { rata skor }\end{array}$ & Kriteria \\
$71 \%$ & Layak \\
\hline
\end{tabular}

Tabel 7. Hasil Validasi oleh Ahli Bahasa

\begin{tabular}{cc}
\hline $\begin{array}{c}\text { Persentase (\%) rata- } \\
\text { rata skor }\end{array}$ & Kriteria \\
$69 \%$ & Layak \\
\hline
\end{tabular}

Kelayakan bahan ajar gamifikasi perolehan dari para ahli yaitu: penilaian ahli materi memberikan skor dengan persentase rata-rata $76 \%$ dikategorikan sangat layak. Ahli media atau desain memberikan skor dengan persentase rata-rata $71 \%$ dikategorikan layak. Sedangkan ahli bahasa memberikan skor dengan persentase rata-rata 69\% dikategorikan layak.

\section{Perbaikan Desain}

Setelah desain produk divalidasi melalui penilaian ahli materi, ahli media, dan ahli bahasa serta guru Matematika SMP Kelas VII, peneliti melakukan revisi terhadap desain produk yang dikembangkan. Perbaikan-perbaikan yang dilakukan terhadap produk yang dikembangkan berpedoman dari masukan-masukan dan saran yang diperoleh dari para ahli validasi

\section{Uji Coba Produk}

Setelah bahan ajar gamfikasi direvisi dan dinyatakan Layak untuk diuji cobakan, kemudian dilakukan uji coba kepada siswa dan guru. Tahap ini disebut dengan tahap uji coba produk. Uji coba produk dilakukan dalam 2 tahapan yaitu 
uji coba kelompok kecil dan uji coba lapangan.

Uji coba kelompok kecil yang terdiri dari 15 responden dan uji coba lapangan yang terdiri dari 30 responden kelas VII di SMP di Bandar Lampung. Hasil ratarata kemenarikan yang diperoleh pada kelompok kecil yang diikuti oleh 15 siswa kelas VII di SMP di Bandar Lampung memperoleh skor rata-rata yaitu 3,6 dan berdasarkan hasil dari angket respon yang telah diisi oleh siswa, hasil ini menempatkan bahan ajar gamfikasi pada kriteria "Sangat Menarik".

Pada uji coba lapangan yang diikuti oleh 30 siswa kelas VII di SMP di Bandar Lampung skor rata-rata kemenarikan yang diperoleh yaitu 3,4 pada kriteria "Sangat Menarik". Uji coba respon guru terhadap bahan ajar gamifikasi diperoleh nilai 3,3 dengan kriteria "Sangat Menarik".

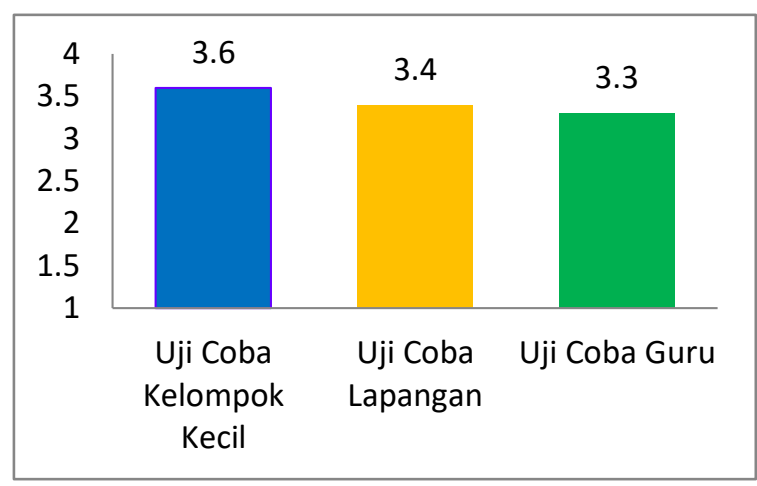

Gambar 2. Persentase Penilaian Uji Coba

Berdasarkan hasil olah data angket respon peserta didik pada uji coba kelompok kecil, uji coba lapangan dan uji coba guru, bahan ajar gamifikasi yang dikembangkan dalam kriteria interpretasi kemenarikan sangat menarik sebagai sumber bahan belajar dan layak digunakan.

Berdasarkan beberapa penelitian terdahulu yang dilakukan oleh Heni Jusuf menunjukkan bahwa dalam proses pembelajaran menggunakan gamifikasi, memberikan alternative untuk membuat proses belajar lebih menarik, menyenangkan, dan efektif (Jusuf,
2016:5). Persamaan hasil penelitian yang dilakukan peneliti menunjukkan bahwa bahan ajar gamifikasi ini dikategorikan sangat menarik dan layak untuk digunakan dalam pembelajaran matematika di sekolah SMP.

Penelitian selanjutnya dilakukan oleh Prambayun dan Mohamad Farozi menunjukkan bahwa hasil penelitian menunjukkan bahwa Respon peserta didik sangat positif (Prambayun \& Farozi, 2015). Persamaan hasil penelitian yang dilakukan peneliti menunjukkan bahwa respon peserta didik pada uji coba kelompok kecil, uji coba lapangan dan uji coba guru, bahan ajar gamifikasi yang dikembangkan dalam kriteria interpretasi kemenarikan sangat menarik sebagai sumber bahan belajar dan layak digunakan.

\section{Revisi Produk}

Selanjutnya yaitu tahap revisi produk. Setelah dilakukan uji coba kelompok kecil, uji coba lapangan dan uji coba guru, diketahui bahwa bahan ajar gamifikasi pada pembelajaran matematika untuk siswa kelas VII SMP memperoleh kriteria "Sangat Menarik", maka dapat dikatakan bahwa bahan ajar gamifikasi ini telah selesai dikembangkan, sehingga dapat menghasilkan produk akhir yang siap untuk digunakan di SMP.

\section{SIMPULAN DAN SARAN}

Berdasarkan hasil penelitian pengembangan maka dapat disimpulkan bahwa kualitas bahan ajar gamifikasi memperoleh beberapa penilaian dari para ahli, yaitu ahli materi, media atau desain dan bahasa dengan memperoleh hasil bahwa bahan ajar gamifikasi pada materi himpunan sangat layak digunakan dalam proses pembelajaran. Selanjutnya respon siswa terhadap bahan ajar gamifikasi diperoleh nilai rata-rata 3,5 dengan kriteria "Sangat Menarik" dan respon guru terhadap bahan ajar 
gamifikasi diperoleh nilai 3,3 dengan kriteria "Sangat Menarik".

Berdasarkan hasil penelitian, analisis, pembahasaan, dan kesimpulan dapat dikemukakan beberapa saran yakni bagi siswa Bahan ajar gamifikasi pada materi himpunan ini dapat layak digunakan, baik secara mandiri maupun kelompok. Bagi pendidik diharapkan dapat memanfaatkan bahan ajar gamifikasi ini untuk menyampaikan materi sehingga selain mempermudah dan membantu pendidik, bahan ajar gamifikasi yang dapat bersifat interaktif juga dapat membuat peserta didik lebih merasa senang, menarik perhatian dan tidak membuat peserta didik jenuh dalam proses pembelajaran sehingga tercipta suasana yang aktif dalam pembelajaran. Bagi peneliti dalam pembuatan bahan ajar gamifikasi pada materi himpunan terdapat beberapa kendala atau kesulitan yang mungkin bisa menjadi perbaikan bagi peneliti yang lain untuk mengembangkan bahan ajar gamifikasi ini dengan desain yang berbeda.

\section{DAFTAR PUSTAKA}

Aisyi, F. K., Elvyanti, S., Gunawan, T., \& Mulyana, E. (2013). Pengembangan Bahan Ajar TIK SMP Mengacu pada Pembelajaran Berbasis Proyek. INVOTEC, IX(2), 117-128.

Farida, Khoirunnisa, Y., \& Putra. (2018). Pengembangan Bahan Ajar Gamifikasi pada Materi Bangun Ruang Sisi Lengkung. JPPM, 11(2), 193-204.

Idi, A. (2014). Pengembangan Kurikulum Teori Dan Praktik. Jakarta: PT Raja Grafindo Persada. Jakarta: PT Raja Grafindo Persada.

Jusuf, H. (2016). Penggunaan Gamifikasi dalam Proses Pembelajaran. Jurnal TICOM, 5(1), 1-6.

Malalina, \& Kesumawati, N. (2013). Pengembangan Bahan Ajar Interaktif Berbasis Komputer Pokok Bahasan
Lingkaran Untuk Kelas VIII Sekolah Menengah Pertama. Jurnal Pendidikan Matematika, 7(2), 56-70. Prambayun, A., \& Farozi, M. (2015). Pola Perancangan Gamifikasi Untuk Membangun Engagement Siswa Dalam Belajar. Seminar Nasional Teknologi Informasi Dan Multimedia ISSN: 2302-3805, 17-22.

Wati, T., Zulkardi, \& Susanti, E. (2015). Pengembangan Bahan Ajar Pmri Topik Literasi Finansial Pada Aritmatika Sosial Kelas VII. Jurnal Pendidikan Madrasah, 9(1), 1-16.

Wekke, I. S., \& Astuti, R. W. (2017). Kurikulum 2013 di Madrasah Ibtidaiyah : Implementasi di Wilayah Minoritas Muslim. Tadris: Jurnal Keguruan Dan Ilmu Tarbiyah, 2(1), 33-39.

https://doi.org/10.24042/tadris.v2i 1.1736 